\title{
PENGARUH PENANGKARAN TERHADAP PERILAKU BURUNG RHEA (Rhea americana) DI TAMAN SAFARI GURUN PUTIH LESTARI, JANTHO ACEH BESAR
}

\section{EFFECTS OF CAPTIVITY ON BEHAVIOR OF RHEA (Rhea americana) \\ IN TAMAN SAFARI GURUN PUTIH LESTARI, JANTHO ACEH BESAR}

\author{
Syifa Salsabila, Gholib Gholib, Mulyadi Adam, Muhammad Jalaluddin, Fadli A. Gani, \\ Muhammad Hambal \\ Fakultas Kedokteran Hewan Universitas Syiah Kuala \\ E-mail: gholib@unsyiah.ac.id
}

(diterima Maret 2021, direvisi Mei 2021, disetujui Juli 2021)

\begin{abstract}
ABSTRAK
Penelitian ini bertujuan untuk mengkaji perilaku harian burung rhea (Rhea americana) di penangkaran Taman Safari Gurun Putih Lestari Jantho, Aceh Besar. Pengamatan perilaku harian dilakukan terhadap 12 individu burung rhea (6 jantan dewasa dan 6 betina dewasa) menggunakan metode scan animal sampling dengan interval pengamatan setiap 10 menit. Data perilaku harian dikelompokkan berdasarkan enam rentang waktu pengamatan, kemudian dianalisis menggunakan Friedman test dan dilanjutkan dengan Mann-Whitney $U$ test untuk mengetahui perilaku harian signifikan per jenis kelamin. Hasil analisis menunjukkan bahwa persentase penggunaan waktu (time budget) melakukan aktivitas harian burung rhea berdasarkan waktu pengamatan menunjukkan perbedaan yang signifikan $(\mathrm{p}<0,05)$ pada perilaku minum dan istirahat, sedangkan perilaku lainnya tidak berbeda nyata $(\mathrm{p}>0,05)$. Berdasarkan jenis kelamin, perilaku makan dan minum betina secara signifikan $(\mathrm{p}<0,05)$ lebih tinggi dibandingkan jantan, sedangkan perilaku termoregulasi, agresi, dan courtship jantan secara signifikan $(\mathrm{p}<0,05)$ lebih tinggi dibandingkan betina. Kesimpulan, penelitian ini menunjukkan terdapat perbedaan variasi perilaku harian burung rhea pada penangkaran berdasarkan waktu pengamatan (perilaku makan dan istirahat), serta perbedaan variasi perilaku harian berdasarkan jenis kelamin (makan, minum, termoregulasi, agresi, dan courtship). Dalam penelitian ini juga teramati perilaku memakan feses (coprophagy) yang belum pernah dilaporkan sebelumnya untuk jenis ini.
\end{abstract}

Kata kunci: penangkaran, perilaku harian, Rhea americana, taman safari.

\begin{abstract}
The study aimed to examine the daily behavior of rhea in captivity of Taman Safari Gurun Putih Lestari Jantho, Aceh Besar. The observation was conducted on 12 individual of rheas (6 adult males and 6 adult females) using the scan animal sampling method with 10 minutes interval. The observation was then grouped based on six time ranges. Data were then analyzed with Friedman test and continued with Mann-Whitney U test to examine the significant daily activities between sexes. The result showed that the time budget for rheas's daily behavior differed significantly $(\mathrm{p}<0.05)$ in drinking and resting activities. Based on sex, females were significantly $(\mathrm{p}<0.05)$ higher than males on eating and drinking activities, while males were significantly $(\mathrm{p}<0.05)$ higher than females on thermoregulatory, aggression and courtship behaviors. In conclusion, there are significant variation on daily behavior of rheas based on observational time range (eating and resting behavior) and sex-based daily behavior (eating, drinking, thermoregulation, aggression, and courtship). This study also observed eating feces behavior (coprophagy) that was not previously reported for this species.
\end{abstract}

Keywords: captivity, daily behavior, Rhea americana, Zoo.

\section{PENDAHULUAN}

Burung rhea (Rhea americana) merupakan hewan endemik dari Amerika Selatan. Jenis burung ini berasal dari keluarga Rheidae yang telah tercantum dalam Appendix II CITES (Sales 2006) dan telah dikategorikan sebagai hewan hampir terancam (near threatened) oleh International Union for Conservation of
Nature/ IUCN (BirdLife International, 2016). Burung rhea merupakan burung besar yang tidak bisa terbang, dengan tinggi antara 93$140 \mathrm{~cm}$ dan berat 22-28 $\mathrm{kg}$ (Bazzano et al. 2011). Burung rhea secara alami umumnya menghuni padang rumput dan semak terbuka, tetapi juga dapat menempati habitat lain, termasuk sabana, hutan terbuka, lahan bersemak, rawa 
asin, padang penggembalaan, lahan pertanian, dan hutan tanaman (Erize \& Villafane 2016). Menurut Sales (2006), selain di habitat alaminya, burung rhea diketahui telah beradaptasi dengan daerah pertanian maju yang kaya akan pangan di Argentina dan Brazil. Burung rhea menyukai daerah terbuka yang bersungai dan daerah dengan vegetasi lebih rendah dari $50 \mathrm{~cm}$.

Burung ini sekarang banyak dipelihara di luar sebaran alaminya di Amerika Selatan, termasuk di Indonesia. Banyak penangkaran maupun kebun binatang memelihara burung ini untuk dijadikan objek ekowisata sekaligus program budidaya dan pengembangbiakan burung rhea. Penangkaran adalah salah satu bentuk konservasi keanekaragaman hayati yang dilakukan di luar habitat alami. Untuk burung rhea, hal ini juga dilakukan di Taman Safari Gurun Putih Lestari Jantho, Aceh Besar, Aceh. Untuk mampu berkembang dalam penangkaran, hewan harus beradaptasi dengan lingkungan kebun binatang. Menurut Mallapur et al. (2005), kemampuan hewan termasuk burung rhea dalam merespon kondisi penangkaran atau kebun binatang sehingga bisa berperilaku normal tergantung sejauh mana kondisi penangkaran/kebun binatang tersebut menyerupai lingkungan alami dari burung rhea. Oleh karena itu, pengetahuan dan pemahaman terkait perilaku harian burung rhea sangat penting dan diperlukan untuk meningkatkan manajemen pemeliharaan dan interpretasi terhadap animal welfare (Csermely et al. 2007).

Penelitian mengenai perilaku burung rhea telah dilakukan sebelumnya oleh Sales (2006) yang menyatakan bahwa bentuk pergerakan normal dari burung rhea, yaitu berjalan dan jarang berlari. Menurut Hambali et al. (2015), pola perilaku di penangkaran mungkin berbeda karena faktor lingkungan yang berbeda. Hal ini sesuai dengan pendapat de Azevedo et al. (2010), perbedaan kondisi habitat akan berdampak terhadap perilaku harian dan persentase penggunaan waktu untuk melakukan aktivitas harian (time budget). Menurut Keetman \& Schapira (2014) di antara kelompok burung ratites (burung thea, burung unta Struthiocamelus, dan burung emu Dromaius novaehollandiae), perilaku harian yang umum diperlihatkan meliputi perilaku makan, mencari makan, minum, berjalan/lokomosi, berdiri/duduk, tidur/istirahat, merapikan bulu, termoregulasi, agresi, serta perilaku sosial seperti bermain dan vokalisasi. Selain perilaku harian di atas, perilaku lain yang dilaporkan, yaitu perilaku seksual meliputi fluttering, menarik perhatian betina, mengerami telur, dan kawin (Codenotti \& Alvarez, 2001). Sebagai tambahan, dilaporkan juga bahwa burung ratites di kebun binatang juga dapat menunjukkan perilaku abnormal yang dilakukan secara berulang-ulang (stereotype behaviors) seperti mondar-mandir, mencabut bulu, mematuk kaki dan wajah secara agresif, serta mengejar dan menendang hewan lain (de Azevedo et al. 2013).

Berdasarkan uraian di atas, maka kajian perilaku harian burung rhea yang dipelihara di luar habitat aslinya diperlukan untuk memastikan kesejahteraan kondisinya. Terlebih, kajian ini belum pernah dilakukan di Taman Safari Gurun Putih Lestari Jantho, Aceh Besar, Aceh. Informasi ini penting sebagai bahan referensi di masa depan untuk digunakan dalam pengelolaan dan pemeliharaan burung rhea di penangkaran, sekaligus sebagai bahan evaluasi terhadap kesejahteraan hewan. Oleh karena itu, tujuan penelitian ini adalah mengkaji perilaku harian burung rhea di penangkaran Taman Safari Gurun Putih Lestari Jantho, Aceh Besar. 


\section{METODE PENELITIAN}

\section{Tempat dan Waktu Penelitian}

Penelitian ini dilaksanakan di Taman Safari Gurun Putih Lestari (GPL), Gampong Cucum, Jantho, Aceh Besar, Aceh pada bulan Februari sampai dengan Maret 2020. Pengamatan dan pencatatan perilaku harian dilakukan dari pukul 10.00 sampai 17.00 WIB.

\section{Alat dan Bahan Penelitian}

Penelitian ini menggunakan stopwatch, lembar catatan aktivitas harian, kamera, dan alat tulis sebagai alat. Adapun objek penelitian adalah 12 individu burung rhea yang terdiri dari 6 ekor jantan dewasa dan 6 ekor betina dewasa yang telah dipelihara selama kurang lebih dua tahun.

\section{Pengamatan dan Pencatatan Perilaku Harian Burung Rhea}

Pengamatan perilaku harian dilakukan dengan metode scan animal sampling dengan mencatat perilaku harian pada beberapa individu burung yang sama dalam interval waktu tertentu (Altmann 1974). Interval waktu yang digunakan dalam pengamatan ini adalah 10 menit. Perilaku harian yang diamati dan etogram perilaku diadopsi dari Codenetti \& Al Varez (2001) dan Keetman \& Schapira (2014) seperti yang disajikan pada Tabel 1.

\section{Pengamatan Kondisi Area Penangkaran Burung Rhea}

Pengumpulan data kondisi penangkaran burung rhea dilakukan melalui pengamatan

Tabel 1. Etogram perilaku pada burung rhea.

\begin{tabular}{|c|c|c|}
\hline Parameter & Jenis perilaku & Definisi \\
\hline \multirow[t]{8}{*}{ Perilaku harian } & Berjalan/lokomosi & Melangkah atau bergerak. \\
\hline & Istirahat (Berdiri/duduk) & $\begin{array}{l}\text { Berdiam baik pada posisi duduk atau berdiri pada satu } \\
\text { tempat tanpa mengerjakan aktivitas. }\end{array}$ \\
\hline & Makan & $\begin{array}{l}\text { Memakan pakan yang tersedia atau makanan lain yang } \\
\text { ada di lingkungan kandang. }\end{array}$ \\
\hline & Minum & Meminum air. \\
\hline & Mencari makan & $\begin{array}{l}\text { Berjalan perlahan mencari makanan di tanah atau } \\
\text { tumbuhan. }\end{array}$ \\
\hline & Merapikan bulu & $\begin{array}{l}\text { Menggosok tubuh dengan paruh secara berulang } \\
\text { dengan pola tertentu. }\end{array}$ \\
\hline & Termoregulasi & $\begin{array}{l}\text { Burung mengembangkan sayap dan membuka mulut } \\
\text { dalam jangka waktu tertentu. }\end{array}$ \\
\hline & Agresi & Mengejar dan/atau menendang hewan lain. \\
\hline \multirow[t]{2}{*}{ Peilaku sosial } & Bermain & $\begin{array}{l}\text { Melakukan interaksi dengan hewan lain umumnya } \\
\text { dengan mengejar. }\end{array}$ \\
\hline & Vokalisasi & Bersuara/menghasilkan suara. \\
\hline \multirow[t]{4}{*}{ Perilaku seksual } & Courtship & $\begin{array}{l}\text { Burung jantan mengepakkan sayap dan mengayunkan } \\
\text { kepalanya untuk menarik perhatian betina, sedangkan } \\
\text { betina reseptif bergabung dengan jantan untuk } \\
\text { melakukan percumbuhan. }\end{array}$ \\
\hline & Kopulasi & Terjadi perkawinan. \\
\hline & Mengeram & Mengerami telur di dalam sarang. \\
\hline & Calling & $\begin{array}{l}\text { Burung jantan bersuara rendah dan nyaring untuk } \\
\text { memanggil betina. }\end{array}$ \\
\hline \multirow[t]{2}{*}{ Perilaku abnormal } & $\begin{array}{l}\text { Mematuk tubuh / } \\
\text { mencabut bulu }\end{array}$ & $\begin{array}{l}\text { Mematuk tubuh atau mencabut bulu secara agresif baik } \\
\text { bulu sendiri maupun pada burung lain. }\end{array}$ \\
\hline & Mondar-mandir & $\begin{array}{l}\text { Burung berjalan mondar-mandir dalam suatu area } \\
\text { secara berlebihan. }\end{array}$ \\
\hline
\end{tabular}


langsung dan wawancara dengan petugas Taman Safari Gurun Putih Lestari. Data yang dikumpulkan berupa luas area penangkaran, fasilitas, dan kelengkapan di area penangkaran.

\section{Analisis Data}

Data kondisi penangkaran burung rhea dianalisis secara deskriptif. Data perilaku harian burung rhea yang diperoleh ditabulasi dan selanjutnya dihitung persentase perilaku harian menggunakan rumus di bawah ini:

Persentase perilaku $x=a / b \times 100 \%$, di mana:

$\mathrm{x}=$ aktivitas yang diamati;

$\mathrm{a}=$ total aktivitas $\mathrm{x}$ selama pengamatan;

$\mathrm{b}=$ total seluruh aktivitas selama pengamatan.

Setelah diperoleh persentase perilaku harian, selanjutnya untuk mengetahui perbedaan persentase perilaku harian berdasarkan waktu pengamatan, maka data persentase perilaku harian dikelompokkan menjadi enam kelompok waktu pengamatan (per satu jam pengamatan, yaitu pukul 10.00-11.00 WIB, 11.10-12.00 WIB, 13.00-14.00 WIB, 14.10-15.00 WIB, 15.10-16.00 WIB, dan 16.10-17.00 WIB) dan selanjutnya dianalisis menggunakan uji

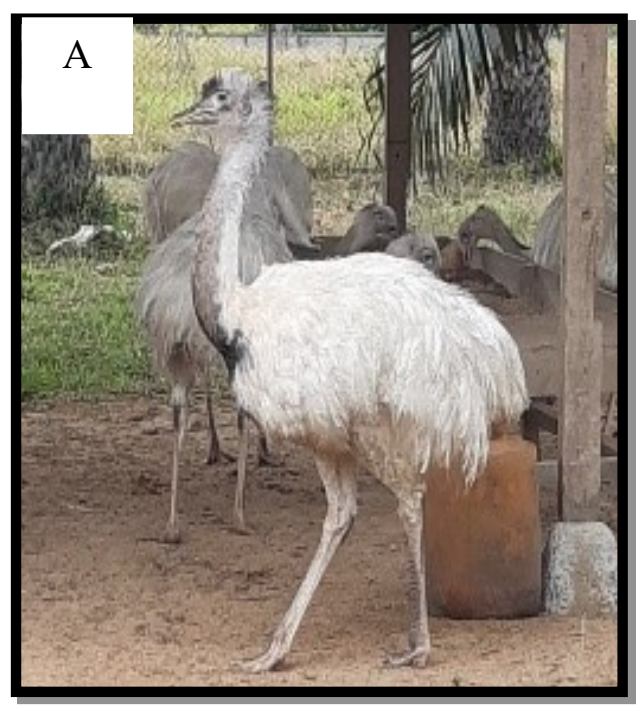

Friedman test untuk mengetahui ada tidaknya perbedaan persentase perilaku harian berdasarkan waktu pengamatan. Untuk mengetahui perbedaan persentase perilaku harian berdasarkan jenis kelamin, maka persentase perilaku harian antara burung rhea jantan dan betina dikelompokkan dan dianalisis menggunakan uji Mann Whitney U test. Uji statistik dilakukan dengan menggunakan program SPSS versi 25.

\section{HASIL DAN PEMBAHASAN}

\section{Habitat Area Penangkaran Burung Rhea}

Taman Safari Gurun Putih Lestari Jantho memelihara 12 individu terdiri dari 6 jantan dewasa dan 6 betina dewasa. Burung rhea mempunyai berat rata-rata $20-27 \mathrm{~kg}$, panjang $129 \mathrm{~cm}$ dari paruh hingga ekor, dan tinggi sekitar 1,50 m. Jantan umumnya lebih besar dari betina. Ciri khusus burung rhea jantan adalah terdapat bulu halus yang banyak (tebal) di atas kepala, sedangkan pada burung rhea betina, tidak terdapat bulu halus atau hanya sedikit di bagian atas kepala (Gambar 1). Bulu burung rhea sangat bervariasi dari putih sampai abu-abu, tetapi umumnya jantan lebih gelap dari betina.

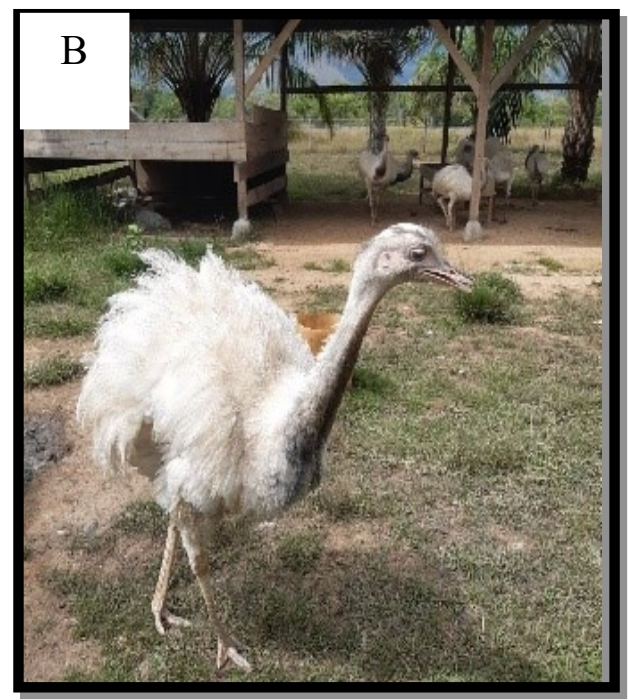

Gambar 1. Burung rhea di Taman Safari Gurun Putih Lestari Jantho. (A) Burung rhea jantan: terdapat banyak rambut halus di atas kepala dan, (B) burung rhea betina: tidak terdapat rambut halus di kepala. Sumber: Dokumentasi pribadi. 


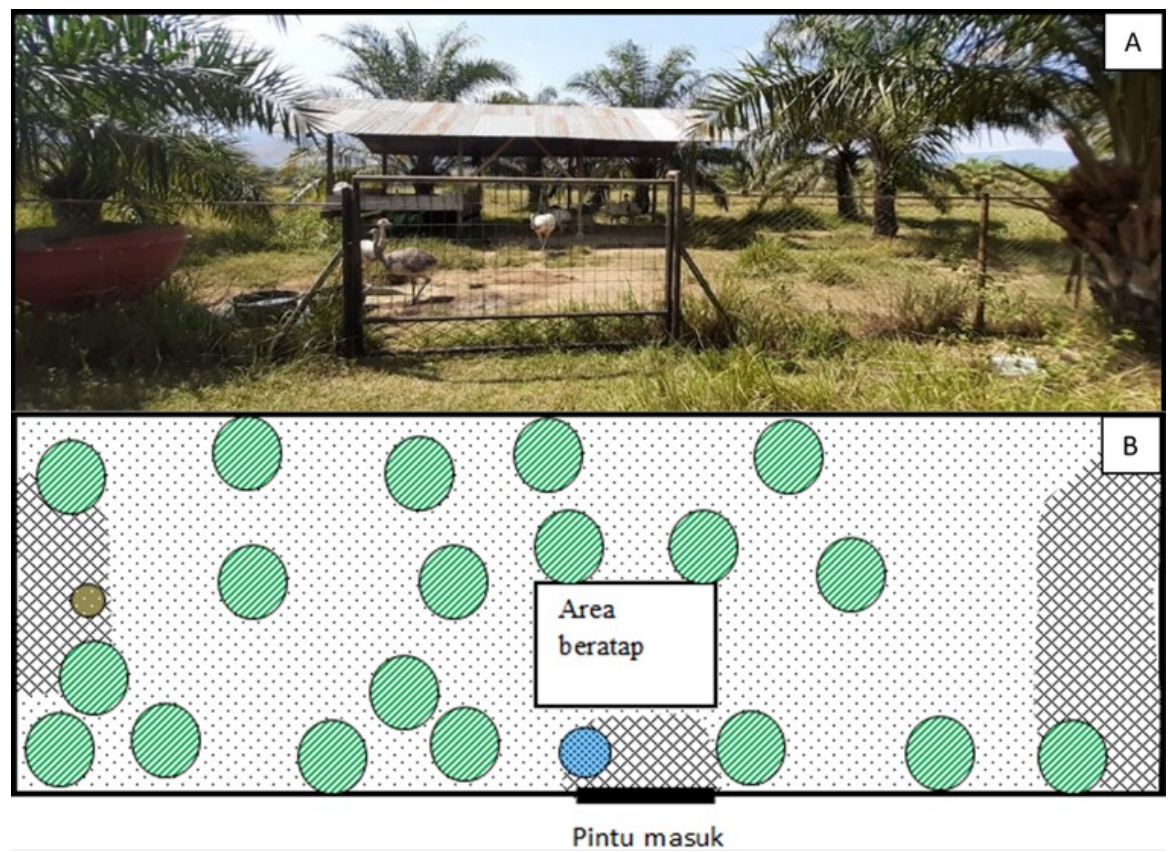

Gambar 2. A) Tampak depan kandang burung rhea, B) Ilustrasi kandang burung rhea di Taman Safari Gurun Putih Lestari $(\%=$ bak air minum, $\mathbb{Z}=$ pohon, $\because=$ sarang burung rhea, $\bigotimes$ = area berpasir, $\because \because$ = area berumput). Sumber: Dokumentasi pribadi.

Hasil pengamatan dan wawancara dengan petugas di Taman Safari Gurun Putih Lestari Jantho, area penangkaran burung rhea memiliki keliling total sekitar 300 meter, sedangkan luas tanah area penangkaran berdasarkan hasil pengukuran melalui kamera satelit (google earth), yaitu $\pm 2.000 \mathrm{~m}^{2}$, dengan area beratap seluas $145 \mathrm{~m}^{2}$. Di area penangkaran terdapat tempat pakan, tempat air minum, pohon, area berpasir, area berumput, dan tempat sarang burung rhea. Pakan yang disediakan berupa dedak dan konsentrat berbentuk pelet. Kondisi area penangkaran burung rhea di Taman Safari Gurun Putih Lestari ditampilkan pada Gambar 2.

Hasil pengamatan terhadap beberapa fasilitas yang terdapat di area penangkaran burung rhea di Taman Safari Gurun Putih Lestari disajikan pada Tabel 2. Berdasarkan Australian Animal Welfare Standards and Guidelines (2019) terdapat beberapa parameter yang menjadi standar tempat penangkaran burung rhea, yaitu adanya pagar dengan ketinggian minimal $1.200 \mathrm{~mm}$, luas kandang $200 \mathrm{~m}^{2}$ per individu, ditambah $100 \mathrm{~m}^{2}$ setiap penambahan 1 ekor burung dewasa. Standar

Tabel 2. Fasilitas yang terdapat di area penangkaran burung rhea di Taman Safari Gurun Putih Lestari Jantho, Aceh Besar.

\begin{tabular}{|c|c|c|}
\hline Fasilitas Penangkaran & Standar $^{1}$ & Hasil Pengamatan \\
\hline Tinggi Pagar & $1.200 \mathrm{~mm}$ & $1.500 \mathrm{~mm}$ \\
\hline Kubangan pasir & Tersedia & Tersedia \\
\hline Kubangan air dangkal & Tersedia & Tersedia \\
\hline Kubangan lumpur & Tersedia & Tersedia ketika hujan \\
\hline Pohon dan semak belukar & Tersedia & Tersedia \\
\hline $\begin{array}{l}\text { Luas area penangkaran atau kandang (untuk } 12 \\
\text { individu dewasa) }\end{array}$ & $1.300 \mathrm{~m}^{2}$ & $\pm 2.000 \mathrm{~m}^{2}$ \\
\hline
\end{tabular}

\footnotetext{
${ }^{1}$ Sumber: Australian Animal Welfare Standards and Guidelines (2019).
} 
lain yang harus dipenuhi untuk penangkaran burung rhea yaitu tersedianya kolam pasir, kolam air dangkal, kolam lumpur, pohon, dan semak belukar. Di area penangkaran, kolam lumpur biasanya tersedia dengan sendirinya ketika musim hujan, tetapi mengering saat musim kemarau. Berdasarkan hasil pengamatan dan standar yang terdapat pada Tabel 2, maka dapat disimpulkan bahwa fasilitas di area penangkaran burung rhea Taman Safari Gurun Putih Lestari, Aceh Besar telah cukup memenuhi standar untuk burung jenis rhea. Bahkan ukuran area penangkaran di sini lebih besar dibandingkan dengan standar yang ditetapkan di dalam Australian Animal Welfare Standards and Guidelines (2019).

\section{Perilaku Harian Burung Rhea}

Persentase penggunaan waktu (time budget) untuk melakukan aktivitas harian (perilaku harian) burung rhea yang diperoleh selama penelitian disajikan pada Gambar 3 . Persentase time budget perilaku harian burung rhea dari tertinggi sampai terendah adalah makan (26,35\%), duduk/berdiri (24,63\%), berjalan $(13,80 \%)$, mencari makan $(10,64 \%)$, minum $(9,60 \%)$, menelisik (5,86\%), termoregulasi $(3,58 \%)$, mengerami telur $(2,48 \%)$, agresi $(1,01 \%)$, courtship $(0,96 \%)$, mondar-mandir $(0,76 \%)$, mencabut bulu $(0,17 \%)$, dan kopulasi (0,17\%) (Gambar 2). Menurut Azevedo et al. (2010) di habitat alami, perilaku berjalan $(28,2 \%)$ dan mencari makan $(35,0 \%)$, perilaku inaktif/istirahat $(11,3 \%)$ dan menelisik $(4,1 \%)$ adalah perilaku yang paling banyak dilakukan burung rhea. Hal ini sedikit berbeda dengan hasil pengamatan di Taman Safari Gurun Putih Lestari, di mana perilaku tertinggi adalah makan, kemudian diikuti oleh perilaku istirahat (duduk/berdiri), berjalan, mencari makan, minum, dan menelisik. Perbedaan ini kemungkinan disebabkan oleh tersedianya makanan dalam jumlah yang melimpah sehingga burung rhea tidak perlu menghabiskan waktu untuk mencari makanannya.

Berdasarkan hasil pengamatan, perilaku makan merupakan perilaku harian tertinggi dari burung rhea. Makan merupakan kebutuhan utama makhluk hidup untuk menjamin kelangsungan hidupnya (Bazzano et al. 2011).

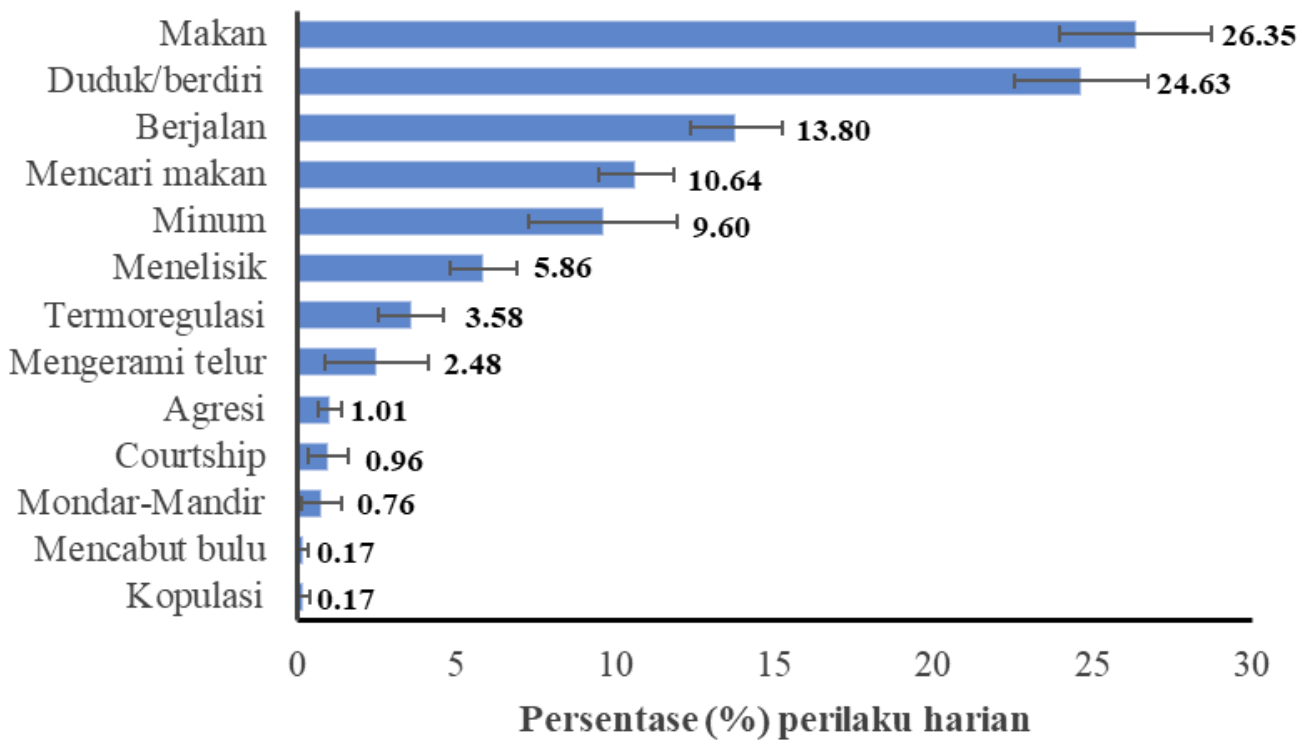

Gambar 3. Persentase time budget perilaku harian burung rhea. 
Selain makanan yang disediakan, burung rhea sering terlihat memakan rumput dan serangga, serta beberapa kali teramati memakan feses dan telur di dalam sarang. Di alam liar burung rhea mengkonsumsi tumbuhan seperti rumput, biji-bijian, dan buah beri, selain juga memangsa serangga, ular, dan tikus (Raikow 1969). Adanya perilaku memakan feses (coprophagy) merupakan hal yang menarik dan perlu dikaji lebih mendalam untuk mengetahui fungsi spesifik perilaku tersebut terhadap burung rhea.

Perilaku coprophagy pada jenis hewan yang berbeda (heterospecific coprophagy), individu berbeda pada jenis hewan yang sama (allocoprophagy), maupun memakan feses sendiri (autocoprophagy) telah dilaporkan pada beberapa jenis hewan (Soave \& Brand, 1991). Perilaku autocoprophagy merupakan perilaku yang berperan dalam mendaur ulang nutrisi dari pakan seperti vitamin, mineral, dan asam amino (Ezenwa et al. 2012). Perilaku allocoprophagy dapat mentransmisi bakteri yang dapat membantu proses percernaan pakan yang terdiri dari serat berselulosa dan juga mendegradasi racun yang ada pada tumbuhan pakan sehingga perilaku ini umum dilaporkan pada mamalia herbivor (Grond et al. 2018; Kohl et al. 2016; Waite \& Taylor, 2014). Menurut Kobayashi et al. (2019), perilaku coprophagy pernah dilaporkan pada burung Japanese rock ptarmigan (Lagopus muta japonica) dan memiliki peran penting dalam proses pencernaan makanan burung tersebut. Oleh karena itu, perilaku coprophagy yang teramati pada burung rhea diduga berperan dalam salah satu hal yang dijelaskan di atas.

Persentase perilaku harian berdasarkan waktu pengamatan per jam dapat dilihat pada Tabel 2. Hasil pengamatan menunjukkan perilaku makan paling tinggi terjadi pada pagi hari (pukul 10.00-11.00 WIB) dan menurun pada siang hingga sore hari. Meskipun secara

Tabel 2. Hasil uji Friedmann persentase perilaku harian pada waktu pengamatan yang berbeda pada burung rhea (rataan \pm standar deviasi, $\mathrm{n}=12$ ).

\begin{tabular}{lccccccc}
\hline \multirow{2}{*}{ Perilaku } & \multicolumn{5}{c}{ Waktu Pengamatan } & Nilai P \\
\cline { 2 - 6 } & $\mathbf{1 0 . 0 0 - 1 1 . 0 0}$ & $\mathbf{1 1 . 0 0 - 1 2 . 0 0}$ & $\mathbf{1 3 . 0 0 - 1 4 . 0 0}$ & $\mathbf{1 4 . 0 0 - 1 5 . 0 0}$ & $\mathbf{1 5 . 0 0 - 1 6 . 0 0}$ & $\mathbf{1 6 . 0 0 - 1 7 . 0 0}$ & \\
\hline Makan & $30,9 \pm 7,8$ & $23,1 \pm 7,8$ & $29,3 \pm 5,7$ & $28,1 \pm 8,7$ & $22,7 \pm 11,6$ & $22,1 \pm 13,5$ & 0,273 \\
Minum & $14,6 \pm 9,5^{\mathrm{a}}$ & $8,6 \pm 6,2^{\mathrm{ab}}$ & $11,8 \pm 6,5^{\mathrm{ab}}$ & $7,9 \pm 6,2^{\mathrm{b}}$ & $7,9 \pm 5,3^{\mathrm{b}}$ & $5,2 \pm 4,3^{\mathrm{b}}$ & $\mathbf{0 , 0 0 8}$ \\
Menelisik & $4,9 \pm 3,1$ & $7,7 \pm 6,1$ & $6,9 \pm 3,2$ & $6,1 \pm 3,2$ & $5,9 \pm 4,4$ & $3,9 \pm 3,6$ & 0,332 \\
Istirahat (duduk/ & $16,7 \pm 1.1^{\mathrm{c}}$ & $25,0 \pm 1.8^{\mathrm{b}}$ & $19,8 \pm 1.7^{\mathrm{c}}$ & $25,9 \pm 0.9^{\mathrm{b}}$ & $31,3 \pm 2.9^{\mathrm{a}}$ & $31,4 \pm 3.2^{\mathrm{a}}$ & $\mathbf{0 . 0 4 8}$ \\
berdiri) & $3,7 \pm 2,9$ & $2,7 \pm 1,9$ & $4,2 \pm 4,4$ & $4,2 \pm 4,3$ & $2,8 \pm 2,9$ & $3,7 \pm 3,5$ & 0.965 \\
Termoregulasi & $13,8 \pm 6,9$ & $16,1 \pm 3,4$ & $14,3 \pm 7,7$ & $10,1 \pm 8,9$ & $13,9 \pm 7,5$ & $14,9 \pm 9,2$ & 0.362 \\
Berjalan & $9,9 \pm 3,4$ & $11,3 \pm 10,5$ & $8,1 \pm 3,6$ & $14,1 \pm 4,1$ & $8,5 \pm 4,1$ & $12,7 \pm 6,7$ & 0,316 \\
Mencari makan & $0,3 \pm 0,8$ & $0,0 \pm 0,0$ & $0,2 \pm 0,4$ & $0,4 \pm 0,9$ & $0,0 \pm 0,0$ & $0,2 \pm 0,5$ & 0,693 \\
Mencabut & $0,0 \pm 0,0$ & $0,8 \pm 2,4$ & $0,0 \pm 0,0$ & $0,0 \pm 0,0$ & $0,0 \pm 0,0$ & $0,4 \pm 0,9$ & 0,416 \\
bulu & $0,9 \pm 1,4$ & $0,6 \pm 1,3$ & $0,5 \pm 1,3$ & $0,0 \pm 0,0$ & $2,1 \pm 2,8$ & $2,1 \pm 3,5$ & 0,285 \\
Kopulasi & $0,9 \pm 2,1$ & $0,8 \pm 1,5$ & $1,3 \pm 2,7$ & $0,0 \pm 0,0$ & $0,8 \pm 2,5$ & $0,5 \pm 1,5$ & 0,658 \\
Agresi & $1,4 \pm 3,8$ & $1,1 \pm 1,9$ & $1,5 \pm 2,6$ & $0,5 \pm 1,5$ & $0,8 \pm 1,9$ & $0,4 \pm 0,9$ & 0,733 \\
Mondar-mandir & $1,9 \pm 3,33$ & $2,1 \pm 3,2$ & $2,4 \pm 3,4$ & $2,8 \pm 3,9$ & $3,1 \pm 4,3$ & $2,6 \pm 3,8$ & 0,364 \\
Courtship & & & & & \\
Mengerami telur & $1,9,3$ &
\end{tabular}

${ }^{\mathrm{a}, \mathrm{b}, \mathrm{c}}$ Superskrip yang berbeda pada baris yang sama menunjukan perbedaan yang nyata $(\mathrm{p}<0,05)$. 


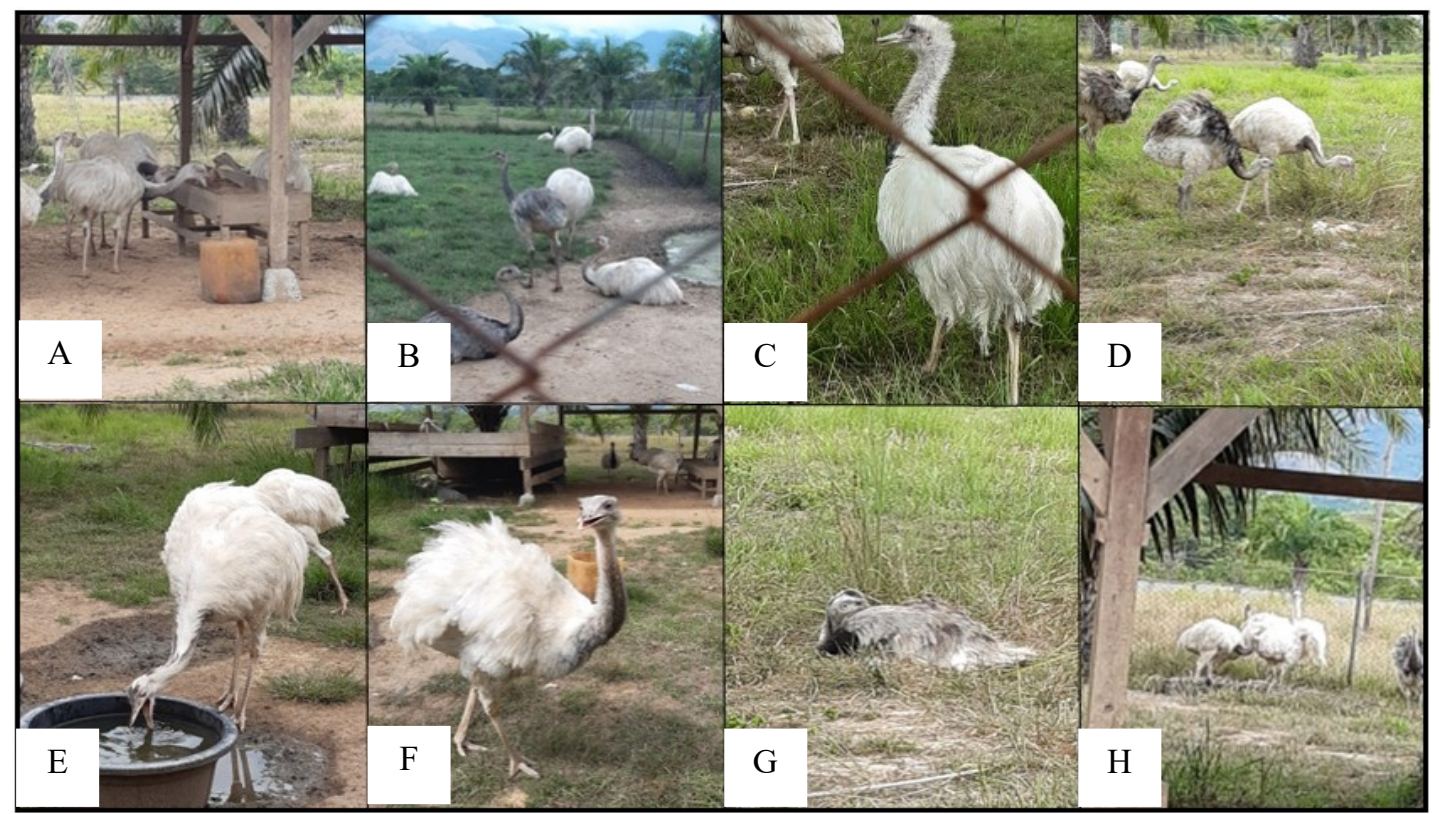

Gambar 4. Dokumentasi perilaku burung rhea. (A) makan, (B) inaktif (duduk/berdiri), (C) berjalan, (D) mencari makan, (E) minum, (F) termoregulasi dengan melebarkan sayap dan membuka mulut, $(\mathrm{G})$ burung jantan mengerami telur, $(\mathrm{H})$ courtship dimana individu jantan melebarkan sayap di samping betina.

statistik hal ini tidak berbeda secara signifikan $(\mathrm{p}>0,05)$. Sama halnya dengan burung rhea di habitat aslinya, mencari makan paling aktif pada pagi hari untuk kemudian menurun di siang dan sore hari (de Azevedo et al. 2010). Selain itu, suhu lingkungan yang relatif lebih rendah di pagi hari memudahkan burung rhea untuk beraktivitas sehingga tidak terdedah dengan panas yang berlebihan pada siang atau sore hari. Pada hewan diurnal, aktivitas makan dan mencari makan lebih banyak terjadi pada pagi hari disebabkan kebutuhan energi untuk melakukan aktivitas hariannya, sedangkan pada siang dan sore hari lebih banyak digunakan untuk beristirahat.

Seiring dengan perilaku makan, burung rhea secara statistik juga minum lebih sering pada pagi hari (10.00-11.00 WIB; $\mathrm{p}<0,05)$ dibandingkan dengan siang atau sore hari (11.00-17.00 WIB). Diduga peningkatan persentase perilaku minum pada pagi hari ini untuk menyeimbangkan kandungan air pada pakan yang umumnya diberikan dalam keadaan kering sehingga lebih mudah untuk dicerna. Dokumentasi perilaku harian pada burung rhea dapat dilihat pada Gambar 4.

Perilaku istirahat burung rhea secara statistik teramati lebih tinggi pada sore hari (15.00-17.00; $\mathrm{p}<0,05)$ dibandingkan pada pagi dan siang hari (10.00-15.00 WIB). Perilaku istirahat ini teramati rendah pada pagi hari disebabkan aktivitas makan dan mencari makan yang tinggi pada rentang waktu ini sehingga saat kebutuhannya telah tercukupi pada siang dan sorenya, mereka cenderung untuk lebih banyak beristirahat. Selain itu, meningkatnya perilaku istirahat ini diduga berhubungan dengan kondisi lingkungan (cuaca dan suhu) yang kurang mengakomodir aktivitas tinggi pada saat tersebut.

Perilaku harian lainnya, seperti menelisik bulu, termoregulasi, berjalan, mencari makan, mencabut bulu, kopulasi, agresi, mondarmandir, courtship, dan mengerami tidak menunjukkan perbedaan yang signifikan ( $p$ $>0,05)$ pada setiap rentang periode pengamatan 
dengan persentase yang lebih kecil dari $10 \%$, kecuali perilaku berjalan dengan persentase 10,07-16,04\% (Tabel 2). Menurut OliveiraSantos \& Tizianel (2008), burung rhea sering dijumpai berjalan di padang terbuka dan sabana pada siang hari. Untuk mengatur suhu tubuh pada siang hari saat mencari makan, maka burung rhea memperlihatkan perilaku termoregulasi dengan sedikit membuka paruh (seperti terengah-engah) atau masuk ke dalam air untuk menurunkan suhu tubuh. Bentuk perilaku termoregulasi yang teramati dilakukan burung rhea di Taman Safari Gurun Putih Lestari, yaitu dengan melebarkan sayap untuk meningkatkan aliran udara dan menurunkan suhu tubuhnya (Gambar 4F).

Perilaku reproduksi sangat sedikit teramati selama penelitian. Sebelum terjadi kopulasi, individu jantan akan melakukan courtship untuk menarik betina dengan cara menghampirinya dengan sayap yang dilebarkan ke depan, berjalan mengikuti betina dengan sesekali mengayunkan kepala, dan bulu pada bagian kepala dan leher terlihat ditegakkan (Gambar 4H). Menurut Sales (2006), perilaku yang digambarkan ini umum dilakukan jantan burung rhea saat mendekati betinanya. Jika terdapat beberapa jantan melakukan courtship secara bersamaan pada satu betina, maka berkemungkinan berakhir dengan tindak agresi. Musim kawin ditandai dengan persaingan seksual yang intens antara burung jantan, tetapi ini tidak akan ditemukan jika terdapat dominasi oleh satu pejantan (Raikow 1969). Pada burung rhea di Taman Safari Gurun Putih Lestari, perilaku agresi terjadi meskipun persentasenya kurang dari 5\%.

Selama penelitian, hanya satu pejantan yang memperlihatkan aktivitas reproduksi dari semua jantan yang ada. Di habitat aslinya, musim berbiak burung rhea berlangsung selama awal musim semi sampai pertengahan musim panas atau sekitar bulan September sampai Februari (Navarro \& Martella 2002). Pejantan yang sama juga membuat satusatunya sarang yang teramati di penelitian ini. Menurut Fernandez \& Reboreda (2003) kegiatan membangun sarang, mengerami telur, dan merawat anakan dilakukan oleh burung rhea jantan. Pengamatan adanya perilaku kawin dan berbiak burung rhea selama penelitian ini mengindikasikan bahwa burung ini dapat bereproduksi di luar masa berbiak dan di luar habitat aslinya, walaupun belum ada anakan yang berhasil menetas. Menurut Navarro \& Martella (2002), di antara burung ratite lainnya, burung rhea memiliki rata-rata keberhasilan reproduksi pada kondisi semi penangkaran (semi captivity) terendah sebesar $20 \%$ dengan persentase keberhasilan telur menetas $58 \%$, dan persentase anak burung bertahan hidup setelah menetas $45 \%$. Oleh karenanya, sangat perlu dicarikan cara untuk meningkatkan keberhasilan reproduksi burung rhea di dalam kandang penangkaran.

\section{Karakteristik Perilaku Burung Rhea Jantan dan Betina}

Hasil pengamatan selanjutnya dikelompokkan berdasarkan jenis kelamin untuk kemudian diuji dengan Mann-Whitney $\mathrm{U}$ test untuk melihat perilaku yang khas di masing-masing jenis kelamin burung rhea. Rata-rata perbandingan perilaku burung rhea jantan dan betina ditampilkan pada Tabel 3 . Secara statistik, betina makan lebih banyak dibandingkan jantan $(30,8 \%$ berbanding $21,8 \%$; p <0,006). Betina juga lebih sering minum dibandingkan jantan $(11,6 \%$ berbanding $6,3 \% ; \mathrm{p}<0,006)$, yang diduga mengikuti tingkat 
Tabel 3. Hasil uji Mann-Whitney U terhadap rataan perilaku burung rhea jantan dan betina (rataan \pm standar deviasi, $\mathrm{n}=12$ ).

\begin{tabular}{lccc}
\hline Perilaku & Jantan & Betina & Nilai P \\
\hline Makan & $21,8 \pm 3,5^{\mathrm{a}}$ & $30,8 \pm 3,5^{\mathrm{b}}$ & $\mathbf{0 . 0 0 6}$ \\
Minum & $6,3 \pm 1,9^{\mathrm{a}}$ & $11,6 \pm 1,2^{\mathrm{b}}$ & $\mathbf{0 . 0 0 6}$ \\
Menelisik & $6,5 \pm 09$ & $5,2 \pm 1,3$ & 0.150 \\
Duduk/berdiri & $24,6 \pm 5,4$ & $25,2 \pm 4,7$ & 1.000 \\
Termoregulasi & $4,8 \pm 0,9^{\mathrm{b}}$ & $2,4 \pm 0,6^{\mathrm{a}}$ & $\mathbf{0 . 0 0 4}$ \\
Berjalan & $14,5 \pm 2,6$ & $13,4 \pm 0,9$ & 0.200 \\
Mencari makan & $11,1 \pm 2,1$ & $10,9 \pm 2,1$ & 0.337 \\
Mencabut bulu & $0,3 \pm 0,2$ & $0,1 \pm 0,1$ & 0.083 \\
Kopulasi & $0,2 \pm 0,4$ & $0,2 \pm 0,3$ & 0.674 \\
Agresi & $1,8 \pm 0,9^{\mathrm{b}}$ & $0,2 \pm 0,3^{\mathrm{a}}$ & $\mathbf{0 . 0 0 6}$ \\
Mondar-mandir & $1,4 \pm 2,9$ & $0,1 \pm 0,3$ & 0.528 \\
Courtship & $1,9 \pm 1,5^{\mathrm{b}}$ & $0,0 \pm 0,0^{\mathrm{a}}$ & $\mathbf{0 . 0 2 2}$ \\
Mengerami telur & $4,9 \pm 11,1$ & $0,0 \pm 0,0$ & 0.317 \\
\hline
\end{tabular}

${ }^{\mathrm{a}, \mathrm{b}}$ Superskrip yang berbeda pada baris yang sama menunjukan perbedaan yang nyata $(\mathrm{p}<0,05)$.

perilaku makan yang juga tinggi. Burung rhea dapat minum setiap saat, tetapi meminum air secara intensif biasanya terjadi setelah burung rhea aktif makan. Burung rhea betina lebih banyak menghabiskan waktu untuk makan, minum, dan mencari makan dibandingkan burung rhea jantan. Hal ini diduga betina perlu untuk menyiapkan cadangan lemak agar dapat menghasilkan telur yang berukuran dan berjumlah optimal saat musim kawin. Hasil ini didukung oleh pernyataan Sales (2006), burung rhea betina lebih banyak menghabiskan waktu untuk nutrisi (mencari makan dan minum) daripada burung jantan.

Burung rhea jantan teramati melakukan aktivitas termoregulasi lebih tinggi dibandingkan rhea betina $(4,8 \%$ berbanding $2,4 \%$; $p$ $<0,004)$. Selama pengamatan, burung rhea betina lebih sering terlihat berada di area beratap untuk makan, sedangkan jantan lebih banyak beraktivitas di kawasan terbuka dan terkena cahaya matahari langsung. Dengan sendirinya, jantan lebih sering melakukan aktivitas termoregulasi untuk beradaptasi dengan suhu tinggi di kawasan terbuka kandang. Selain itu, kebiasaan mencari makan dan berjalan pada siang hari juga dapat menyebabkan burung rhea terpapar suhu tinggi dalam waktu yang lebih lama (Oliveira-Santos \& Tizianel 2008).

Perilaku agresi yang meliputi unjuk dominansi, perebutan betina, dan menjaga sarang teramati lebih tinggi pada jantan dibandingkan betina ( $1,8 \%$ berbanding $0,2 \%$; $\mathrm{p}<0,006)$. Musim kawin biasanya ditandai dengan persaingan seksual yang intens antara burung jantan di mana banyak terlihat aktivitas yang bersifat agonistik. Burung jantan juga dapat memperlihatkan display mengancam saat sedang mengerami telurnya jika didekati oleh burung rhea lain. Perilaku courtship merupakan perilaku yang lebih dominan ditunjukkan oleh burung rhea jantan untuk menarik perhatian burung betina $(1,9 \%$ berbanding $0,0 \% ; \mathrm{p}<0,022)$. Burung rhea jantan memiliki peran dominan dalam reproduksi, dimulai dari melakukan courtship display, membangun sarang, mengerami telur, dan 
merawat anak burung setelah menetas (Navarro \& Martella 2002, Fernandez \& Reboreda 2003).

\section{KESIMPULAN}

Terdapat perbedaan variasi perilaku harian burung rhea di penangkaran Taman Safari Gurun Putih Lestari, Jantho Aceh Besar berdasarkan waktu pengamatan, yaitu perilaku minum pada pagi hari $(14,6 \%)$ dan istirahat pada sore hari $(31,4 \%)$. Selain itu, berdasarkan jenis kelamin juga terdapat perbedaan variasi perilaku harian, yaitu perilaku makan dan minum lebih tinggi pada betina, sedangkan pada jantan perilaku yang lebih tinggi adalah termoregulasi, agresi, dan courtship. Dalam penelitian ini juga teramati perilaku memakan feces (coprophagy) yang sebelumnya belum pernah dilaporkan untuk jenis burung ini.

\section{UCAPAN TERIMA KASIH}

Penulis mengucapkan terima kasih kepada Bapak Tgk. Abdul Hafid Al-fairusy Al -baghdady (Cut Fit Alfairusy Albaghdady) yang telah memberikan izin melakukan penelitian di Taman Safari Gurun Puth Lestari, Jantho Aceh Besar, Aceh. Ucapan terima kasih juga penulis sampaikan kepada para petugas di Taman Safari Gurun Putih Lestari, Jantho Aceh Besar, Aceh atas bantuan selama penelitian dan kepada dua reviewer anonim atas saran dan masukannya terhadap artikel ini.

\section{DAFTAR PUSTAKA}

Altmann, J. (1974). Observational study of behavior: sampling methods. Behaviour, 49(3), 227267. DOI: $10.1163 / 156853974 x 00534$

Australian Animal Welfare Standards and Guidelines. (2019). Guide Exhibited
Animals Ratites. [Online]. Diambil dari http: www.animalwelfarestandards.net.au files/2019/07/guide-exhibited-animals-ratites.pdf

Bazzano, G., Navarro, J.L., \& Martella, M.B. (2011). Diet preference and breeding success in captive-breed Greater Rheas (Rhea americana): a preliminary study. Turk. J. Vet. Anim. Sci., 35(1), 33-39. DOI:10.3906/vet-0904-25

BirdLife International. (2016). Rhea americana. The IUCN Red List of Threatened Species 2016: e.T22678073A92754472 https:// dx.doi.org/10.2305IUCN.UK.20163.RL TS.T22678073A92754472.en. Downloaded on 03 July 2021.

Codenotti, T.L. \& Alvarez, F. (2001). Mating behaviour of the male greater rhea. The Wilson Bulletin, 113(1), 85-89. https:// doi.org/10.1676/0043-5643(2001)113 [0085:MBOTMG]2.0.CO;2

Csermely, D., Gaibani, G., \& Dardani, E. (2007). Year-round behavioural sequences in captive ostrich (Struthio camelus domesticus) pairs. Applied Animal Behaviour Science, 103(1-2), 156-166. DOI: 10.1016/j.applanim.2006.04.018 de Azevedo, C.S., Ferraz, J.B., Tinoco, H.P., Young, R.J., \& Rodrigues, M. (2010). Time-activity budget of greater rheas (Rhea americana, Aves) on a humandisturbed area: the role of habitat,time of the day, season and group size. Acta Ethol, 13, 109-117. https:// doi.org/10.1007/s10211-010-0080-7 de Azevedo, C.S.D., Lima, M.F.F., Cipreste, C.F., Young, R.J., \& Rodrigues, M. (2013). Using environmental enrichment to reduce the expression of abnormal behaviours in Greater Rhea Rhea americana at Belo Horizonte Zoo. 
International Zoo Yearbook, 47 (1), 163

-170.DOI: 10.1111/j.1748-1090.2012.00195.x

Erize, F.G. \& Villafane, I.E.G. (2016). Habitats selected by the endangered Greater Rhea (Rhea americana) - implication for conservation. Emu-Ausral Ornithology, 116(4),379-386.https://doi.org/10.1071/MU15124

Ezenwa, V.O., Gerardo, N.M., Inouye, D.W., Medina, M., \& Xavier, J.B. (2012). Animal behaviour and the microbiome. Science, 338(6104), 198-199. DOI: $10.1126 /$ science. 1227412

Fernandez, G. J. \& Reboreda, J. C. (2003). Male parental care in greater rheas (Rhea americana) in Argentina. The Auk, 120(2), 418-428.

Grond, K., Sandercock, B.K., Jumpponen, A., \& Zeglin, L.H. (2018). The avian gut microbiota: community, physiology and function in wild birds. J. Avian Biol., 49 (11): e01788. https://doi.org/10.1111/jav.01788

Hambali, K., Zakaria, N., Fauzi, N., \& Amir, A. (2015). Behaviour of captive ostriches (Struthiocamelus) at Universiti Malaysia Kelantan, Bachok Campus, Kelantan, Malaysia. Journal of Tropical Resources and Sustainable Science, 3, 13-17.

Keetman, L. \& Schapira, C. (2014). The welfare of Ostriches, Emus, Rheas and Marabou Storks in Mixed-Species Enclosure in Zoos in the Netherlands. Leeuwarden, Netherlands: Whitley Wildlife Conservation Trust.

Kobayashi, A., Tsuchida, S., Ueda, A., Yamada, T., Murata, K., Nakamura, H., \& Ushida, K. (2019). Role of coprophagy in the cecal microbiome development of an herbivorous bird Japanese rock ptarmigan. The Journal of Veterinary Medical
Science, 81(9), 1389-1399. doi: 10.1292/ jvms.19-0014

Kohl, K.D., Connelly, J.W., Dearing, M.D., \& Forbey, J.S. (2016). Microbial detoxification in the gut of a specialist avian herbivore, the Greater Sage-Grouse. FEMS Microbiol Lett.,363(14):fnw144. doi: 10.1093/femsle/fnw144

Mallapur, A., Sinha, A., \& Waran, N. (2005). Influence of visitor presence on the behavior of captive lion-tailed macaques (Macacasilenus) housed in Indian zoos. Applied Animal Behaviour Science, 94 (3), 341-352. DOI: 10.1016/ j.applanim.2005.02.012

Navarro, J.L. \& Martella, M.B. (2002). Reproductivity and raising of Greater Rhea (Rhea americana) and Lesser Rhea (Pterocnemia pennata) - a review. Arch. Geflugelk, 66 (3), 124-132.

Oliveira-Santos, L.G.R. \& Tizianel, F.A.T. (2008). Influence of temperature on greater rhea Rhea americana activity in restinga habitat, southern Brazil. Revista Brasileina de Ornitologia, 16(1),29-31.

Raikow, R.J. (1969). Sexual and agonistic behavior of the common rhea. The Wilson Bulletin, 81(2), 196-206.

Sales, J. (2006). The rhea, a ratite native to South America. Avian and Poultry Biology Reviews, 17(4), 105-124. DOI: $10.3184 / 147020606783438759$

Soave, O. \& Brand, C.D. (1991). Coprophagy in animals: a review. Cornell Vet., 81 (4), 357-364.

Waite, D.W. \& Taylor, M.W. (2014). Characterizing the avian gut microbiota: membership, driving influences, and potential function. Front. Microbiol., 5, 223. doi: 10.3389/fmicb.2014.00223 